\title{
Integration of different influencing factors in GIS to delineate groundwater potential areas using IF and FR techniques: a study of Pravara basin, Maharashtra, India
}

\author{
Sumit Das ${ }^{1} \mathbb{( B}$. Sudhakar D. Pardeshi ${ }^{1}$
}

Received: 21 November 2017 / Accepted: 5 October 2018 / Published online: 15 October 2018

(c) The Author(s) 2018

\begin{abstract}
In the present days, remote sensing and geographic information system (GIS) techniques are comprehensive tools for the assessment of water resource, its management and conservation. In this study, remote sensing and GIS techniques are taken into consideration for zonation of different groundwater prospects of Pravara basin. Several contributing factors in which groundwater potential of an area entirely or partially depends such as lithology, geomorphology, slope, soil, lineament density, drainage density, land use and rainfall are assessed individually as well as together for making the different groundwater prospect maps through influencing factor (IF) and frequency ratio (FR) techniques. In ArcGIS software, all these thematic layers are prepared using different satellite imageries and conventional data sets, obtained from different sources. All these layers are transformed into high-resolution raster format and meshed together in GIS environment using IF and FR methods. Groundwater prospect maps are constructed as a result of overlay analysis. Based on the constructed map of groundwater prospect zones, as a result of this study, the study area is divided into five categories of different groundwater potential zones: very high, high, moderate, low and very low. Validation of the resultant maps has shown that frequency ratio technique is having higher accuracy (AUC $=73 \%)$ compared to the influencing factors $(\mathrm{AUC}=69 \%)$. The present study of groundwater zonation provides a simple and less time-consuming technique; also, the results can directly be used for planning and sustainable management in Pravara basin.
\end{abstract}

Keywords Groundwater potential $\cdot$ Lineament $\cdot$ GIS $\cdot$ Sustainable management $\cdot$ IF technique $\cdot$ Pravara

\section{Introduction}

Water resource is more than anything else, which makes the Earth unique in the solar system. About $71 \%$ of the Earth's surface is covered by water, still there is a severe crisis of freshwater for drinking, agriculture and industries because $97 \%$ water on the earth is salt water in the form of seas and oceans, about $2 \%$ water is glaciers in the polar region, and remaining $1 \%$ is a form of stream channels and groundwater (WWAP 2009). Only stream channels and groundwater are the sources of freshwater. Surface water is highly vulnerable to various pollutants. Hence, surface water in many places is not a good option for the human consumption and economic

Sumit Das

sumit.das.earthscience@gmail.com

1 Department of Geography, Savitribai Phule Pune University, Pune 411007, India activities (Todd and Mays 2005; Hoque et al. 2009; Babiker et al. 2007; Mogaji et al. 2015). The availability of water also varies spatially depending on the climate. Insufficient water availability in arid and semi-arid areas causes repeated drought condition. Hence, management of freshwater is very significant in order to prevent severe water scarcity in arid and semi-arid regions (Das and Pardeshi 2018a).

Aquifers containing groundwater in the sub-surface are highly localized and change spatially (Satpathy and Kanungo 1976). Therefore, researchers are highly interested towards mapping the different potential areas for groundwater. The availability of groundwater depends on several factors such as geology, geomorphology, slope, soil texture, drainage density, lineament concentration, rainfall and land use of an area (Sander et al. 1996; Nag 2005; Sener et al. 2005; Solomon and Quiel 2006; Ganapuram et al. 2009; Singh et al. 2011b; Magesh et al. 2012; Mukherjee et al. 2012; Das et al. 2017, 2018; Das and Pardeshi 2018b). Hence, a sincere assessment of these parameters can provide a clear 
understanding regarding the groundwater potential of a region. Additionally, assessment of these parameters develops a general knowledge regarding the importance of each and every factor for groundwater potential in different areas around the world.

Currently, remote sensing and GIS techniques play a crucial role in the assessment of Earth's natural resources (Das et al. 2018). These techniques are highly cost-effective and less time-consuming to understand the groundwater potential of a region (Murthy 2000; Leblanc et al. 2003; Jha and Peiffer 2006; Prasad et al. 2008; Pradhan 2009; Arkoprovo et al. 2012; Manap et al. 2013; Mallick et al. 2015; Rahmati et al. 2015; Das et al. 2017); the main reason is the availability of satellite data which make the analysis easier (Ganapuram et al. 2009) compared to the traditional techniques such as ground drilling, geophysical assessment of lineaments and field observations (Das et al. 2017, 2018; Das and Pardeshi 2018b). Integration of different environmental factors to delineate groundwater potential zone gave satisfactory results of many previous works (Krishnamurthy et al. 1996; Rao and Jugran 2003; Lokesha et al. 2005; Khan et al. 2006; Solomon and Quiel 2006; Avtar et al. 2010; Dar et al. 2010; Jha et al. 2010; Elewa and Qaddah 2011; Magesh et al. 2012; Bagyaraj et al. 2013; Rahmati et al. 2015; Kirubakaran et al. 2016; Roy and Sahu 2016; Tahmassebipoor et al. 2016; Das et al. 2017). Several methods are very prevalent to delineate different groundwater prospect zones using remote sensing and GIS such as multi-criteria decision (Mukherjee et al. 2012; Kumar et al. 2014; Machiwal and Singh 2015; Das et al. 2017), frequency ratio model (Davoodi et al. 2013; Naghibi et al. 2015), logistic regression model (Ozdemir 2011), boosted regression tree (Naghibi et al. 2016) and many other geostatistical (Mallick et al. 2015) and mathematical models. All these methods are very common and widely used by numerous researchers around the world as well as in India to evaluate the availability and distribution of groundwater resources.

Due to the highly variable geological conditions in the hard-rock region, groundwater potential mapping is more complex and challenging (Kellgren 2002; Mukherjee et al. 2007; Anbazhagan et al. 2011; Balamurugan et al. 2017). Many scholars carried out their researches to explore groundwater potential in basaltic terrain (Baker et al. 2003; Cherkauer 2004; Das et al. 2017; Pande et al. 2017). However, the demarcation of the groundwater prospect areas in the Deccan Trap region of Maharashtra, covered by flood basalt, is still not studied well. Hence, an attempt has been made in this study to demarcate different groundwater potential areas of the Pravara basin by using multi-criteria modelling (influencing factor and frequency ratio) in GIS environment. Several environmental criteria such as geology, geomorphology, soil texture, lineament concentration, drainage, regional slope, rainfall distribution and land-use pattern have been evaluated to prepare the groundwater potential maps for future planning, management, utilization and conservation of groundwater resources in the Pravara basin.

\section{Study area}

Pravara basin is located in the north-eastern part of Western Ghat, India. Geographically, the study area is situated in between $19^{\circ} 25^{\prime} \mathrm{N}$ to $19^{\circ} 45^{\prime} \mathrm{N}$ latitude and $73^{\circ} 35^{\prime} \mathrm{E}$ to $74^{\circ} 50^{\prime} \mathrm{E}$ longitude, in Ahmednagar district, Maharashtra, India, encompassing an area about $2600 \mathrm{~km}^{2}$ (Fig. 1). Pravara and its tributaries are the main drainage system of this basin, and they contribute a significant amount of water to the Godavari river which is the largest river system in peninsular India after Ganga. Western section of the basin has extremely hilly landscape, whereas the eastern part is characterized by relatively flat and gentle plateau. Pravara basin shows a moderate relief variation, ranging from 404 to $1424 \mathrm{~m}$ above sea level. The entire basin consists of extrusive basalt flow of the Cretaceous-Tertiary period, named as Deccan Volcanic Province (Wellman and McElhinny 1970; Alexander 1981; Widdowson and Mitchel 1999; Hooper et al. 2010).

Pravara basin shows semi-arid climatic condition due to its geographical location. Western Ghat stays as a barrier of south-west monsoon to enter into the intercontinental part (Doke et al. 2018). Therefore, the study area shows semiarid characteristics during the non-monsoon period of a year (October-May).

\section{Data and methodology}

\section{Geospatial database preparation}

The methodology which was followed in this study to demarcate different groundwater prospect zones in Pravara basin is shown in Fig. 2. With the help of the geological quadrangle map, lithology map of the Pravara basin was prepared, and the geological quadrangles were acquired from the Geological Survey of India (GSI). Drainage network map of the study area was drawn by using SRTM DEM in ArcGIS 10.3 software. Hydrology tools were employed to delineate drainage network. Pravara basin is having a very limited number of ground weather stations, and because of this problem, grid-based rainfall data were selected to prepare rainfall distribution map (www.worldclim.org). To understand the monthly rainfall characteristics, rainfall data of Ahmednagar district are obtained from http://indiawater portal.org/ website for a span of 1992-2002. Soil texture 


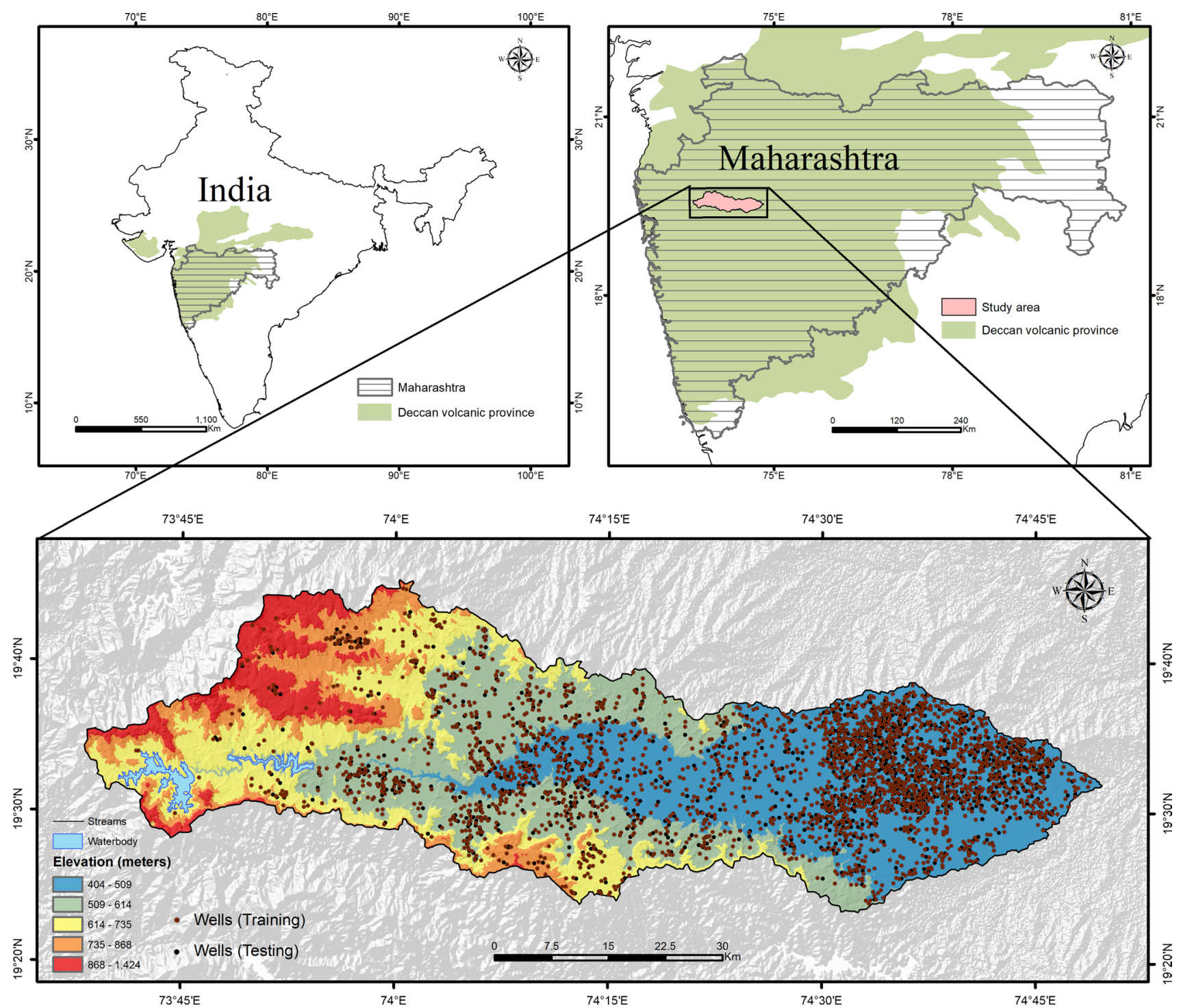

Fig. 1 Location map of the study area with reference to Maharashtra State and India. The inset green layer is representing the Deccan Volcanic Province which is one of the greatest geological formations in India

data were acquired from National Bureau of Soil Survey (NBSS) to prepare the soil texture map of the Pravara basin. SRTM DEM was processed in ArcGIS under spatial analysis tool to prepare slope map.

Das and Pardeshi (2018b) demonstrated that Cartosat DEM provides a highly detailed shaded relief map which provides higher surface information compared to the SRTM and ASTER DEM. Therefore, shaded relief maps of eight different azimuth angles were developed from Cartosat DEM in order to extract the lineaments of the Pravara basin (Das et al. 2018). All the physical linear features were traced manually from the hill-shaded map. After the preparation of lineament map, line density command was used to prepare lineament concentration map of the Pravara basin. Preparation of lineament map was extended up to creating the rose diagram, which denotes an advanced understanding of the alignment of lineaments.

IRS LISS-III images of $23.5 \mathrm{~m}$ spatial resolution were considered in this study for the preparation of land-use map of the Pravara basin using ERDAS Imagine 2014 software.

\section{Influencing factors}

All the thematic maps created previously were resampled into raster layers of 30-m spatial resolution. After that, interrelationship was made between all these factors and the weights assigned to each factor depending on their interrelationship and influence capability (Fig. 3). The interrelationship is adapted in this study based on the prior knowledge of different influencing factors for groundwater potential in different 
Fig. 2 Methodology considered for the present study
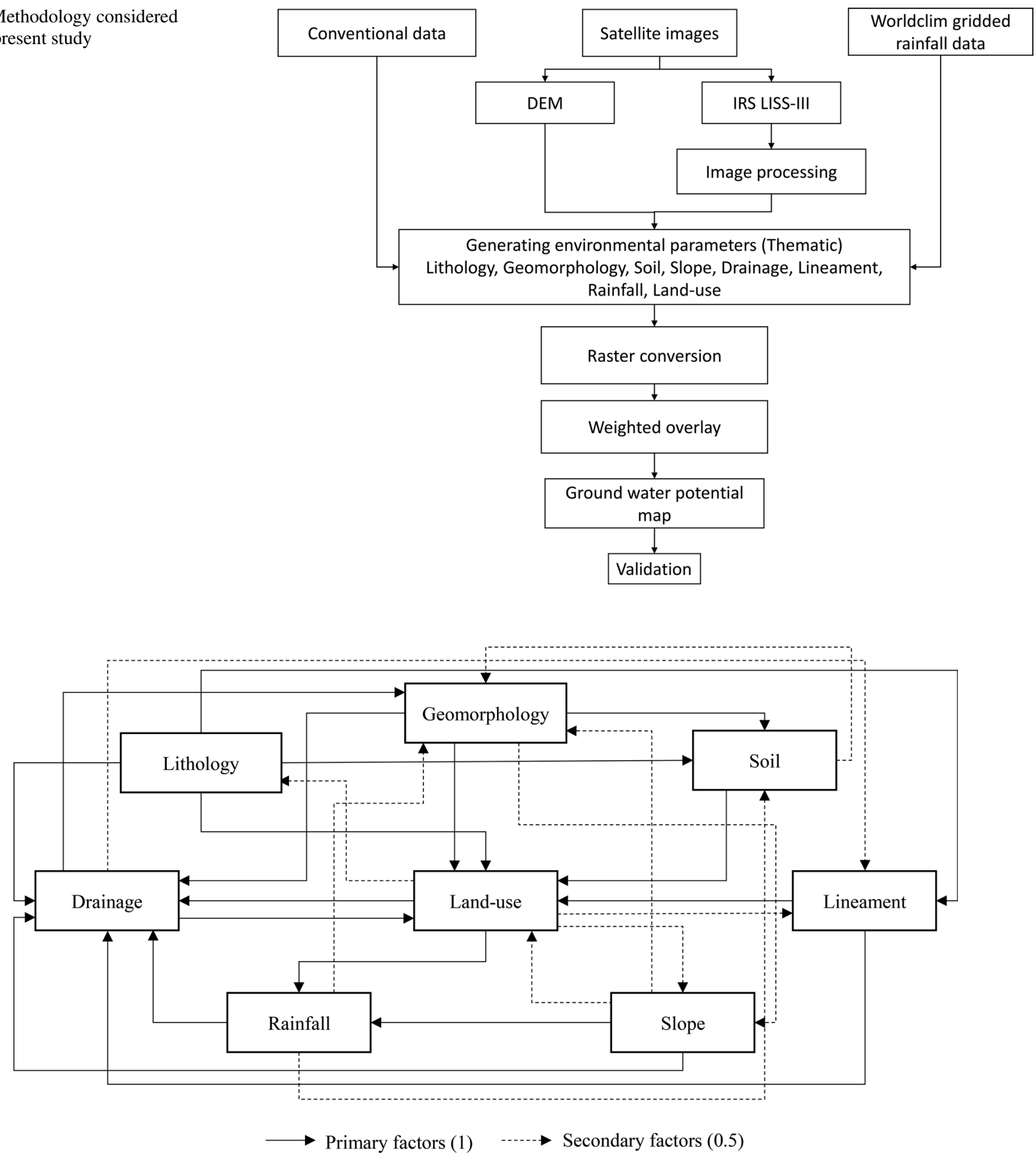

Fig. 3 Interrelationship between factors which influence groundwater potential. Source Modified after Magesh et al. (2012)

regions using the extensive literature review (Krishnamurthy et al. 1996; Rao and Jugran 2003; Lokesha et al. 2005; Solomon and Quiel 2006; Avtar et al. 2010; Jha et al. 2010; Magesh et al. 2012; Bagyaraj et al. 2013; Rahmati et al. 2015; Tahmassebipoor et al. 2016; Das et al. 2017). Based on the interrelationship among all factors, a score of 1 and a score of 0.5 were assigned to the parameters for successfully influencing other parameter(s) directly and indirectly according to its strength (Yeh et al. 2009) (Table 1). For instance, in our study area, lithology (mainly mafic basalt) is having a direct relationship with four factors for groundwater potential (lineament, drainage, soil, and land use). Therefore, a value of 4 was assigned for lithology. Similarly, geomorphology (undulating plateau, pediment and alluvial flood plain) has major influence on drainage network, soil and land use with minor impact on slope; hence, weight of 3 for major influences and 0.5 for 
Table 1 Influencing factors, their major-minor effects and corresponding scores. Source Modified after Magesh et al. (2012), Das et al. (2017)

\begin{tabular}{llllc}
\hline Factors & Major effect $\left(M_{j}\right)$ & Minor effect $\left(M_{i}\right)$ & $\begin{array}{l}\text { Proposed value } \\
\left(M_{j}+M_{i}\right)\end{array}$ & $\begin{array}{l}\text { Proposed score } \\
\text { for each factor } \\
\left(P_{i}\right)\end{array}$ \\
\hline Lithology (rock type) & $1+1+1+1$ & 0 & 4 & 18 \\
Geomorphology & $1+1+1$ & 0.5 & 3.5 & 16 \\
Land-use pattern & $1+1$ & $0.5+0.5+0.5$ & 3.5 & 16 \\
Slope & $1+1$ & $0.5+0.5$ & 3 & 14 \\
Drainage density & $1+1$ & 0.5 & 2.5 & 11 \\
Lineament density & $1+1$ & 0 & 2 & 9 \\
Rainfall & 1 & $0.5+0.5$ & 2 & 9 \\
Soil texture & 1 & 0.5 & 1.5 & 7 \\
& & & $\sum 22$ & $\sum 100$ \\
\hline
\end{tabular}

Refer Fig. 3 to understand the interrelation between all factors considered in this table for major and minor effects

minor influence was assigned to geomorphology. However, the interrelationship among all these factors is changeable subject to the different characters of lithology, geomorphology and land use with area.

The given formula was used to calculate the scores for each influencing factor (Das et al. 2017):

$\left[\frac{\left(M_{j}+M_{i}\right)}{\sum\left(M_{j}+M_{i}\right)}\right] \times 100$

where $M_{j}$ represents major interrelations among two factors and $M_{i}$ represents minor interrelation among two factors.

All these thematic maps were integrated into ArcGIS software; after computation of scores, rank classification was done by dividing the previous scores $\left(P_{i}\right)$ by the number of classifications in each factor. After that, the class having highest influence, a same score of weight $\left(P_{i}\right)$ was assigned and the scores were reduced equally according to the previous calculation (Table 2). For instance, lithology is having a score of 16 as weight and the study area is characterized by only two types of lithological categories (basalt and alluvium). Therefore, the first type of lithology having higher influence gets a score of 16 , while the second one gets 8 . The expression gives better understanding of classification and assigning ranks in each category:

$W_{i}$ of first class $=P_{i}$

[e.g. $P_{i}$ of lithology 18 ; notice Table 1 where the ranks are shown by $P_{i}$. Therefore, $W_{i}$ of first class of lithology $=P_{i}$ value $=18]$

$W_{i}$ of second class $=W_{i}$ of first class $-\left(P_{i} / n\right)$

[e.g. 16- $(18 / 2)=9$ ] [notice that lithology has 2 class; therefore, $n=2]$

$W_{i}$ of third class $=W_{i}$ of second class $-\left(P_{i} / n\right)$ where $W_{i}$ is the rank value of each class, $P_{i}$ the weight of each factor, and $n$ is the total number of classes in each factor.

Thereafter, weighted overlay was done to delineate groundwater potential map of the Pravara basin by using the following equation (Das et al. 2017):

Priority zone $(P)=\sum_{i=1}^{n}\left(P_{i} * W_{i}\right)$

where $P$ represents the priority zones, $P_{i}$ represents weight of each factor, and $W_{i}$ represents rank of each class.

\section{Frequency ratio}

Frequency ratio is a very popular and useful statistical approach which is frequently used for geospatial assessment of the probabilistic relationship among different variables. Several studies have implemented frequency ratio for groundwater potential mapping (Manap et al. 2014; Pourtaghi and Pourghasemi 2014).

Frequency ratio can be defined as the ratio of the area to the groundwater wells. The model is based on the correlation and observed relationship between different influencing factors and the availability of the wells in each factor. The calculation of FR can be done using following formula:

$\mathrm{FR}=\frac{W / G}{M / T}$

where $W$ is the number of pixels with wells for each contributing factor; $G$ is the total number of wells in the study area; $M$ is the number of pixels in each class of a contributing factor; and $T$ is the total number of pixels in a contributing factor. 
Table 2 Classification of weighted factors and their corresponding ranks to delineate groundwater potential zones

\begin{tabular}{|c|c|c|c|c|c|}
\hline Factors & Classes & Ranking $\left(W_{i}\right)$ & $M / T$ & $W / G$ & FR \\
\hline \multirow[t]{2}{*}{ Lithology } & Alluvium & 18 & 0.93 & 0.91 & 0.98 \\
\hline & Basalt & 9 & 0.07 & 0.09 & 1.29 \\
\hline \multirow[t]{4}{*}{ Geomorphology } & Younger floodplain & 16 & 0.12 & 0.19 & 1.60 \\
\hline & Older alluvial plain & 12 & 0.16 & 0.40 & 2.42 \\
\hline & Pediment & 8 & 0.27 & 0.27 & 0.98 \\
\hline & Lava plateau & 4 & 0.15 & 0.15 & 0.33 \\
\hline \multirow[t]{7}{*}{ Land-use } & Water body & 16 & 0.00 & 0.00 & 0.00 \\
\hline & Agricultural land & 14 & 0.41 & 0.49 & 1.20 \\
\hline & Agricultural land dry & 12 & 0.10 & 0.18 & 1.80 \\
\hline & Natural vegetation & 10 & 0.04 & 0.07 & 1.75 \\
\hline & Scrub forest & 8 & 0.03 & 0.02 & 0.67 \\
\hline & Barren land (rocky outcrop) & 6 & 0.33 & 0.15 & 0.45 \\
\hline & Settlement & 4 & 0.09 & 0.08 & 0.89 \\
\hline \multirow[t]{5}{*}{ Slope } & $0^{\circ}-3.92^{\circ}$ & 14 & 0.15 & 0.92 & 6.15 \\
\hline & $3.92^{\circ}-9.15^{\circ}$ & 11 & 0.45 & 0.07 & 0.16 \\
\hline & $9.15^{\circ}-16.02^{\circ}$ & 8 & 0.26 & 0.01 & 0.03 \\
\hline & $16.02^{\circ}-26.81^{\circ}$ & 5 & 0.11 & 0.00 & 0.01 \\
\hline & $26.81^{\circ}-83.05^{\circ}$ & 2 & 0.02 & 0.00 & 0.00 \\
\hline \multirow[t]{5}{*}{ Drainage density $\left(\mathrm{km} / \mathrm{km}^{2}\right)$} & $1.18-1.80$ & 11 & 0.11 & 0.12 & 1.16 \\
\hline & $0.93-1.18$ & 9 & 0.23 & 0.30 & 1.29 \\
\hline & $0.71-0.93$ & 7 & 0.28 & 0.32 & 1.16 \\
\hline & $0.46-0.93$ & 5 & 0.23 & 0.18 & 0.76 \\
\hline & $0-0.46$ & 3 & 0.15 & 0.07 & 0.49 \\
\hline \multirow[t]{5}{*}{ Lineament density $\left(\mathrm{km} / \mathrm{km}^{2}\right)$} & $2-3$ & 9 & 0.04 & 0.00 & 0.11 \\
\hline & $1.2-2$ & 8 & 0.10 & 0.01 & 0.11 \\
\hline & $0.5-1.2$ & 6 & 0.14 & 0.04 & 0.31 \\
\hline & $0.2-0.5$ & 4 & 0.19 & 0.20 & 1.02 \\
\hline & $0-0.2$ & 2 & 0.54 & 0.75 & 1.39 \\
\hline \multirow[t]{5}{*}{ Rainfall (mm) } & $1700-2355$ & 9 & 0.05 & 0.00 & 0.08 \\
\hline & $1350-1700$ & 8 & 0.05 & 0.00 & 0.06 \\
\hline & $950-1350$ & 6 & 0.12 & 0.03 & 0.24 \\
\hline & $650-950$ & 4 & 0.18 & 0.12 & 0.63 \\
\hline & $465-650$ & 2 & 0.60 & 0.85 & 1.42 \\
\hline \multirow[t]{6}{*}{ Soil } & Deep loam & 7 & 0.05 & 0.03 & 0.60 \\
\hline & Slightly deep loam & 6 & 0.19 & 0.14 & 0.76 \\
\hline & Shallow loam & 5 & 0.11 & 0.06 & 0.61 \\
\hline & Very shallow clay loam & 4 & 0.22 & 0.06 & 0.27 \\
\hline & Deep clay & 3 & 0.37 & 0.67 & 1.80 \\
\hline & Slightly deep clay & 2 & 0.06 & 0.03 & 0.48 \\
\hline
\end{tabular}

After calculation of frequency ratio, the groundwater potential map is prepared by summation of frequency ratio values of each contributing factors and their sub-categories through the following equation:

Priority zone $(P)=\sum_{i=1}^{n} \mathrm{FR}$

where FR is the frequency ratio value of each factor and their sub-categories.

\section{Results and discussion}

Eight different influencing factors such as lithology, geomorphology, drainage, soil, lineaments, slope, rainfall and land use are inspected to demarcate different groundwater prospect zones of the Pravara basin. Below, a detailed discussion is given based on the results of this study. 


\section{Lithology}

Extensive basalt rock of the Cretaceous-Tertiary period is the primary rock type of Pravara basin (Fig.4). The finegrained basalts over the study area are pyroxene enriched. This basalt shows various types of flows, such as aa flow, compound and sheet pahoehoe flows (Bondre et al. 2004; Brown et al. 2011). Central part of the Pravara basin shows very thick (about $30 \mathrm{~m}$ ) alluvium deposition of the Quaternary period, overlie the basalt along the main stream and its tributaries (Bondre et al. 2006; Das 2017). This fine and thick alluvium is deposited by the Pravara stream network.

\section{Geomorphology}

The study area shows four major geomorphic divisions which are lava plateau, pediment, older alluvial plain and younger flood plain (Fig. 5). Western part of the basin shows prominent lava plateau with structural topography. Top of these structures can be considered as Mesa and Buttes due to the flat topographical condition. Central

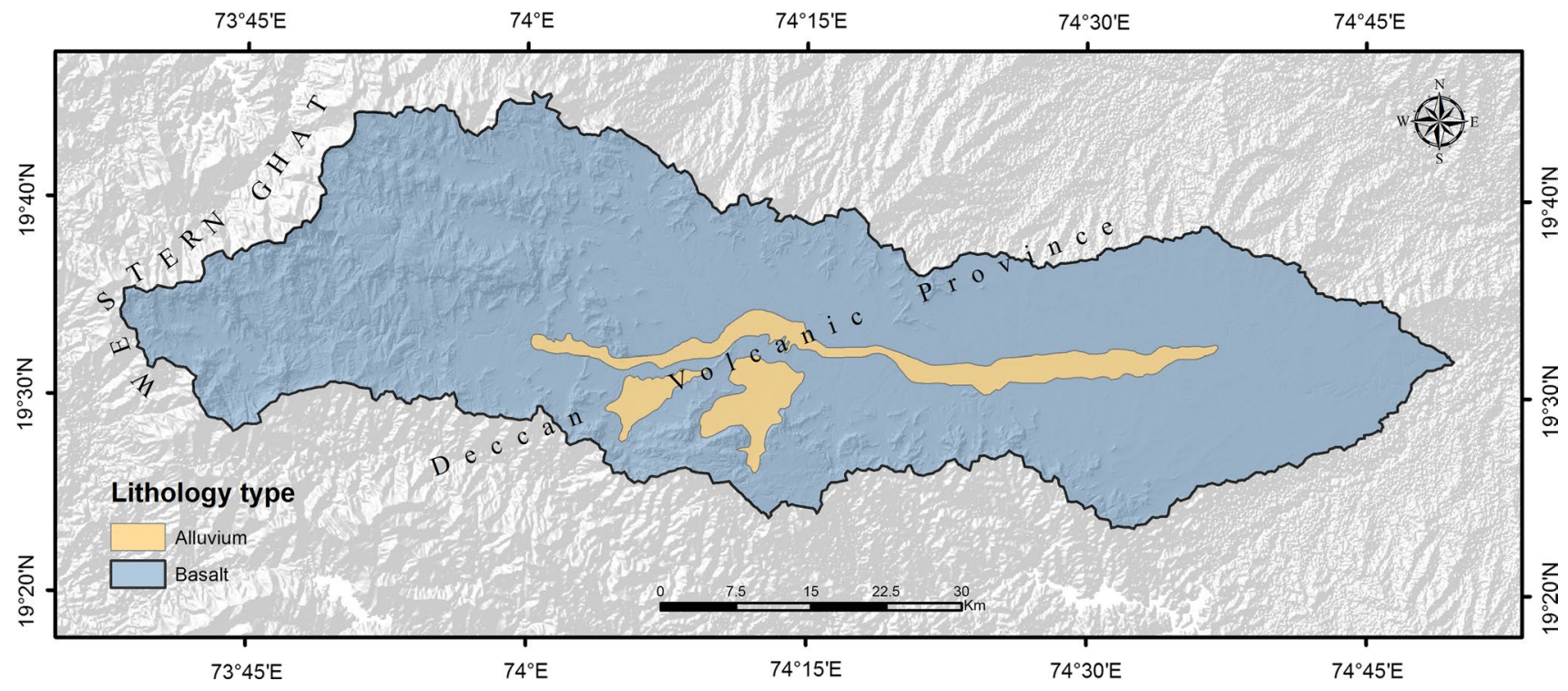

Fig. 4 Lithology map of the study area

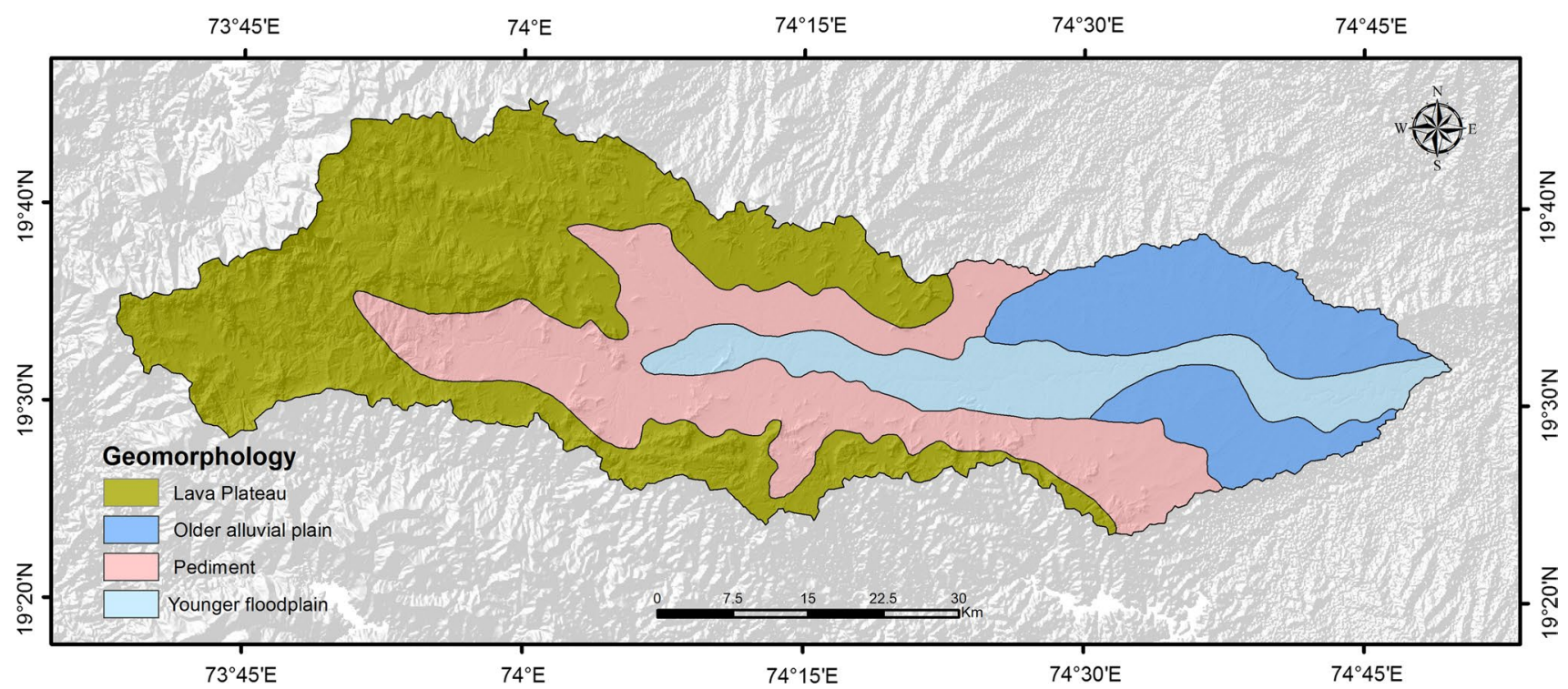

Fig. 5 Geomorphology map of the study area 
region of the study area is characterized by an almost gentle pediment. An elongated stretch of younger alluvium is found in the central part and eastern region of the Pravara basin, covering the older alluvium deposition.

\section{Land use}

The major land-use patterns in the Pravara basin are barren land $(33.5 \%)$, dry agricultural land $(20 \%)$, agricultural land (19.7\%), scrub forest $(15.8 \%)$, natural vegetation (5\%), settlement (5\%) and water bodies (1\%) (Fig. 6). Regions with very high built-up and concrete constructions are bad for groundwater potential because of more surface run-off, while agricultural lands are good due to the availability of loose soil on the surface (Singh et al. 2010, 2011a; Das et al. 2017)

\section{Slope}

The slope is one of the important factors which controls the groundwater potential of a region. Rapid run-off occurs in the case of steep slope due to the higher velocity of the water (Das 2018). In the gentle slope region, the water becomes stagnant in a particular place for a longer duration which influences water to penetrate into soil layers (Das 2018). Based on the slope map, the entire study area has been divided into five major divisions. $1^{\circ}-4^{\circ}$ slope is ideal for very good groundwater potential due to the flat terrain. $4^{\circ}-9^{\circ}$ slope falls into good groundwater potential (Fig. 7). Area having slope in between $9^{\circ}$ and $16^{\circ}$ is considered as moderate, $16^{\circ}-26^{\circ}$ is selected for low as the slope is steep and more than $26^{\circ}$ is taken as very low groundwater potential as these areas reflect very steep slope where very rapid run-off occurs (Das et al. 2017; Kumari et al. 2017a, b)

\section{Drainage density}

Drainage density is the total length of streams per unit area (Avtar et al. 2011a). Drainage density map of Pravara basin is intended by utilizing the line density tool in ArcGIS. Depending on the result, five classes are prepared. The groups are assigned to different groundwater potentials as very high $\left(1.18-1.80 \mathrm{~km} / \mathrm{km}^{2}\right)$, high $\left(0.93-1.18 \mathrm{~km} / \mathrm{km}^{2}\right)$, moderate $\left(0.71-0.93 \mathrm{~km} / \mathrm{km}^{2}\right)$, low $\left(0.46-0.93 \mathrm{~km} / \mathrm{km}^{2}\right)$ and very low $\left(0-0.46 \mathrm{~km} / \mathrm{km}^{2}\right)$. Figure 8 illustrates drainage density map where higher density is found in the central and the eastern section of the Pravara basin.

Several studies suggest that regions having lower drainage density are having more groundwater potential as run-off is higher on the impermeable rock (Bagyaraj et al. 2013; Jenifer and Jha 2017; Thomas and Duraisamy 2017). However, water generally follows the slope and accumulates in the region having lowest elevation of an area irrespective of lithological setting. In semi-arid regions, river beds characterized by alluvium or sedimentary rock (or other rock consist pores) can actively contribute substantial amount of water for groundwater recharge if the groundwater table is lower than the river bed (Yeh et al. 2009). Additionally, as drainage is the local base level of an area, thus, sub-surface flow accumulates near streams which leads to higher groundwater availability near streams.

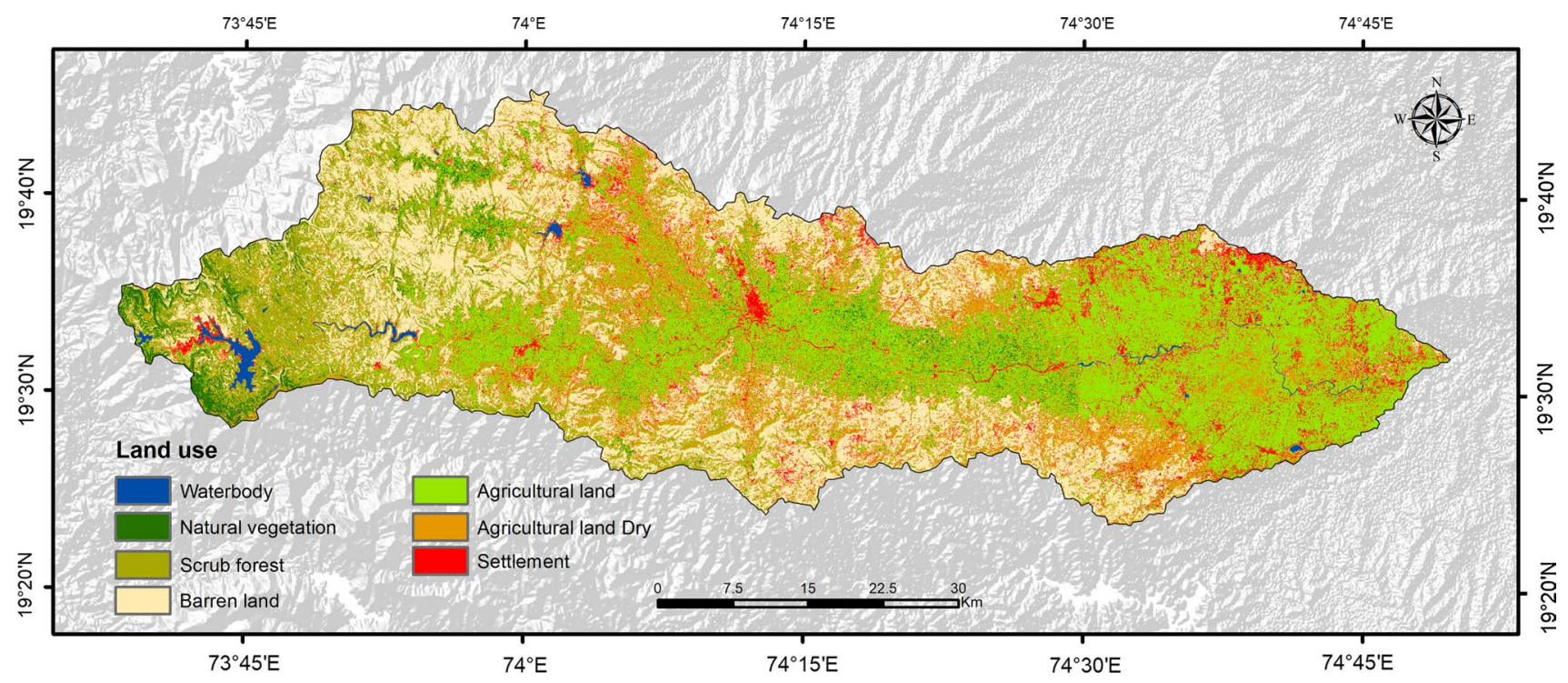

Fig. 6 Land-use map of the study area 


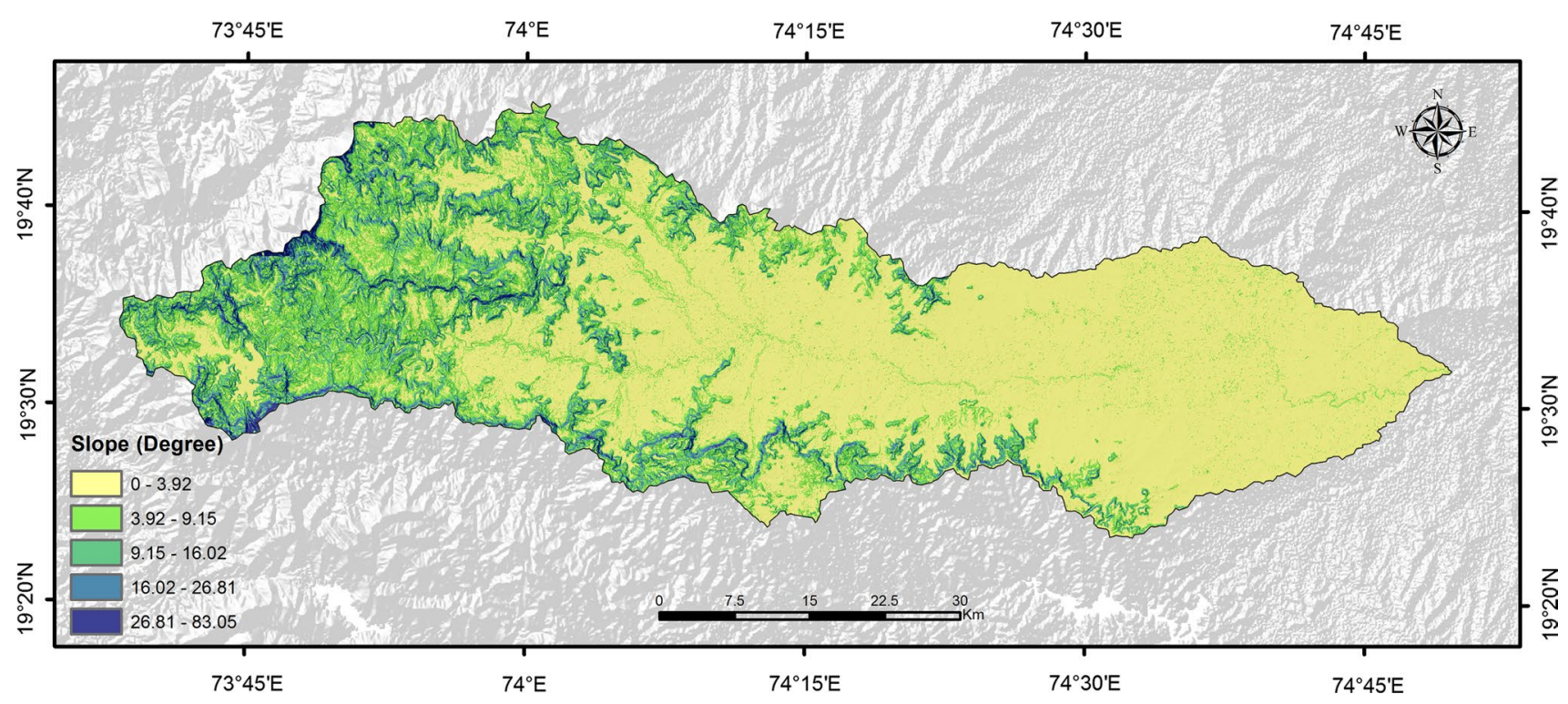

Fig. 7 Slope map of the study area

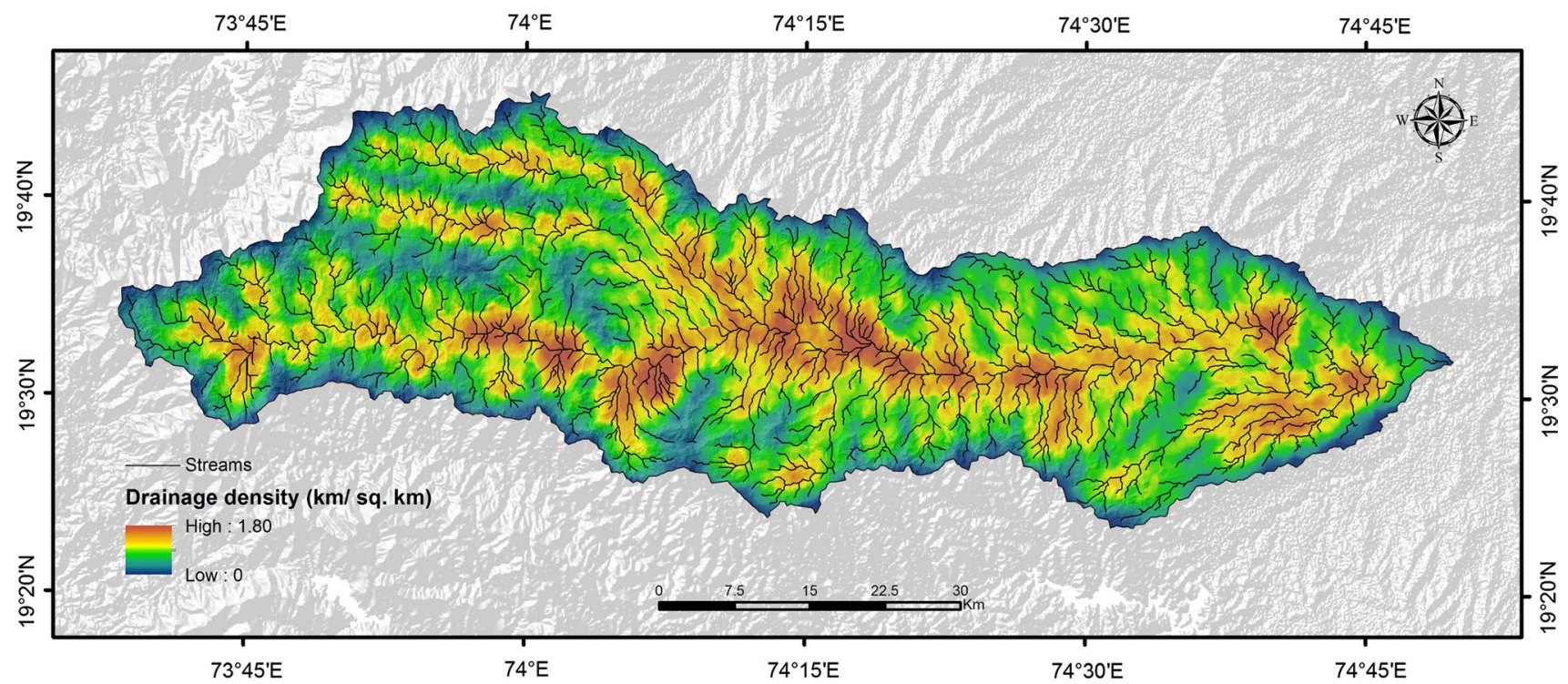

Fig. 8 Drainage density map of the study area

\section{Lineament density}

Lineaments are basically the weakness of topography such as joints, cracks, faults and shears. In hard-rock lithology due to lower porosity of terrain, groundwater potentiality generally depends on other structural features (Kumanan and Ramasamy 2003; Avtar et al. 2011b; Singh et al. 2011b; Das and Pardeshi 2018b; Das et al. 2018). Hence, lineaments play a fundamental role in groundwater potential as the structural weakness increases the infiltration capacity. Areas having a higher density of lineaments are basically having a good groundwater potential. Figure 9 illustrates the lineament density map of the study area where it can be observed that the western section of the study area is characterized by very dense lineaments.

\section{Rainfall}

Pravara basin is a part of semi-arid peninsular India, where rainfall occurs only during monsoon season. Average annual 


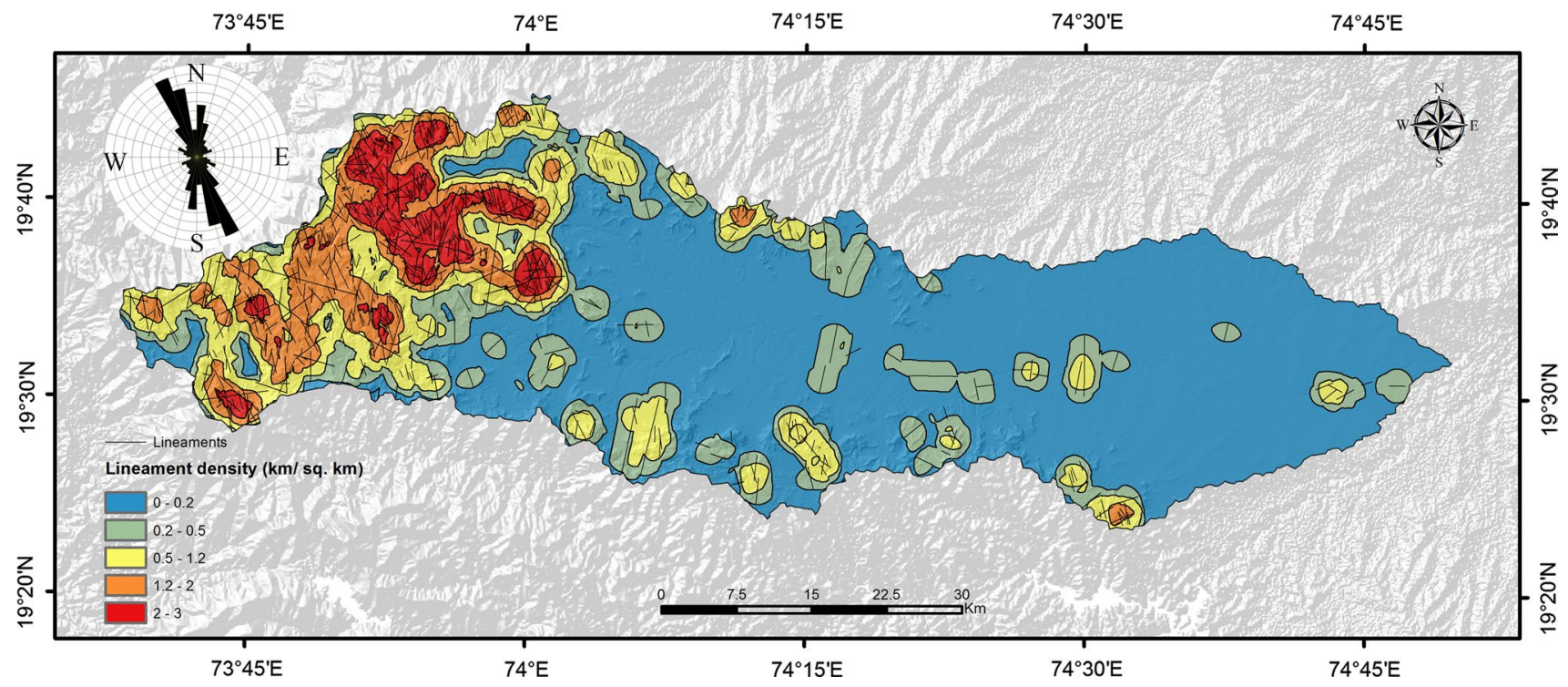

Fig. 9 Lineament density map of the study area. Straight lines are representing geological linear features in the study area. The inset rose diagram is illustrating the orientation of lineaments within Pravara basin (modified after Das et al. 2018)

rainfall of the study area is about $650 \mathrm{~mm}$. Fugure 10 is illustrating the average annual rainfall distribution in the study area. From June to September, monsoon rain occurs in Pravara basin and the rainfall starts decreasing gradually from the October month of the year (Fig. 11). Almost no rainfall occurs for the period of January-May, and during this time severe water resource scarcity occurs in the study area due to lack of water availability. Western section of the Pravara basin shows higher annual rainfall due to the south-west monsoon which brings high amount of water vapour in this area and creates orographic rainfall (Doke et al. 2018). The eastern part of the Pravara basin experiences very low amount of rainfall because after orographic rainfall in west, very little amount of water vapour remains in the atmosphere (Kumari et al. 2017c, d).

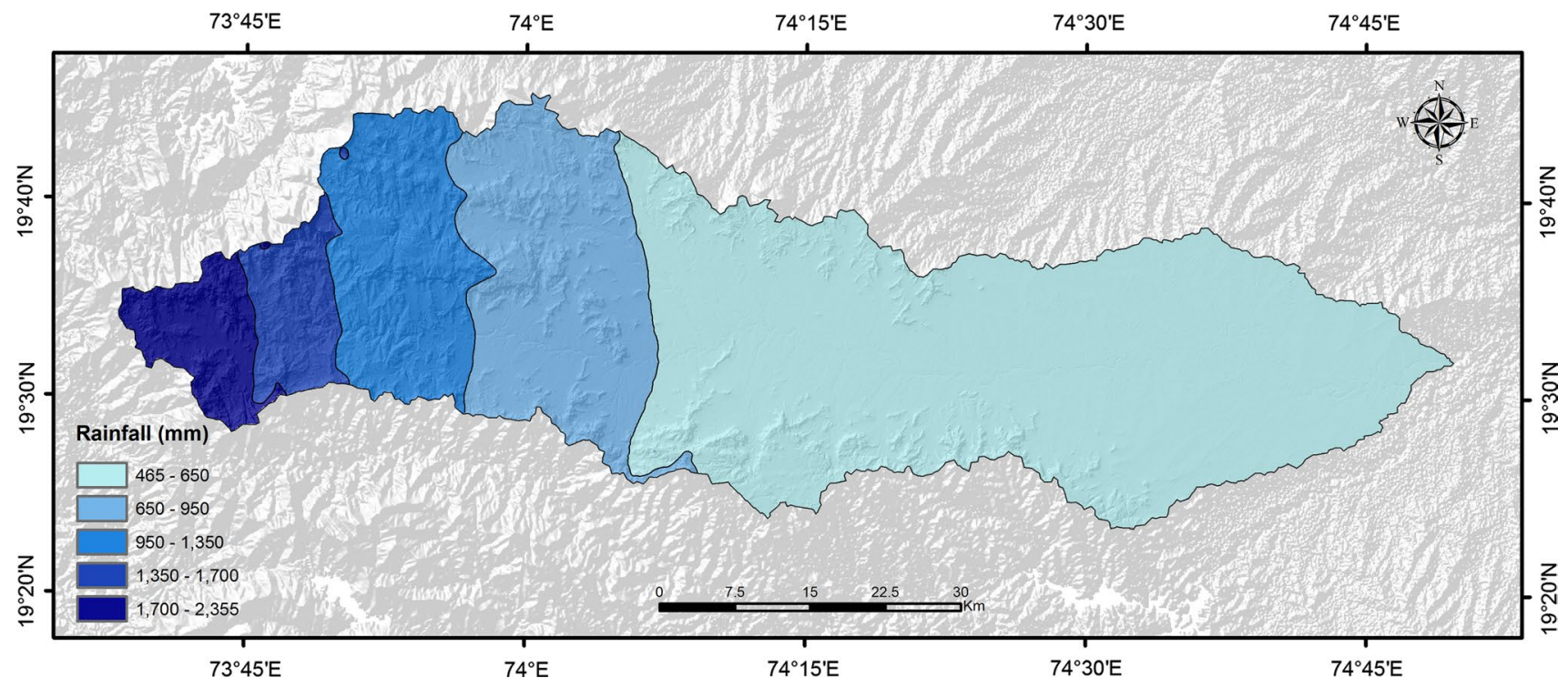

Fig. 10 Rainfall distribution map of the study area 
Fig. 11 Monthly rainfall distribution of the study area. The blue bar and the red line are indicating amount of rainfall and temperature, respectively

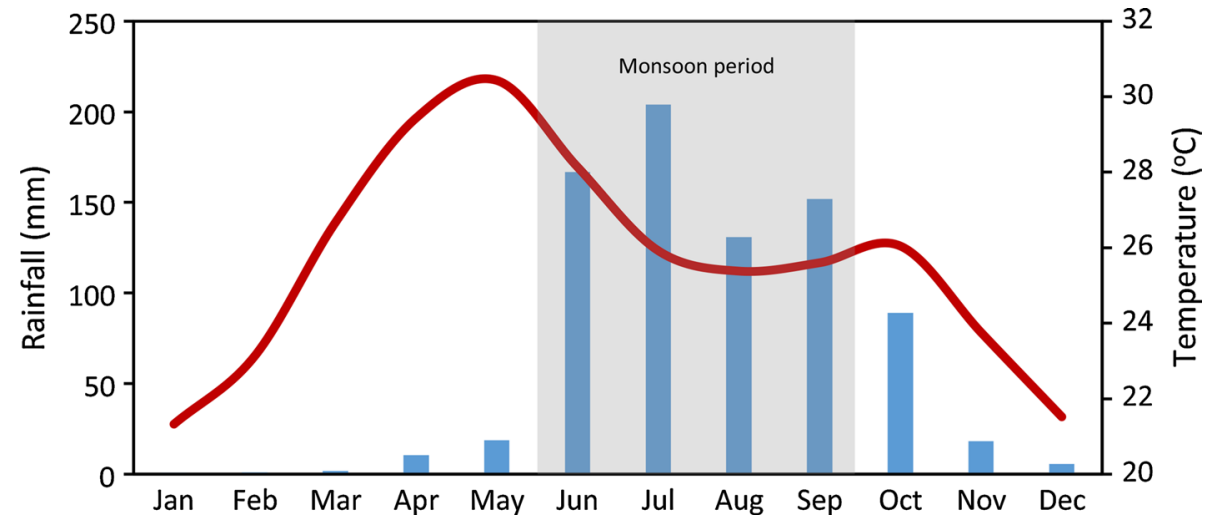

\section{Soil}

Soil texture and depth are having a major impact on the groundwater potentiality of an area (Mehra et al. 2016; Mehra and Singh 2018). Soil distribution map of the Pravara basin was prepared from the soil map of Maharashtra (Fig. 12). The major soil texture found in the study area is clay and loam. The thickness of soil varies place to place. The western part of Pravara basin is characterized by very shallow soil deposition, whereas the alluvial plain next to the main river is characterized by moderate to deeply buried soil.

\section{Delineation of different groundwater potential areas}

By using remote sensing and GIS, several influencing factors such as lithology, geomorphology, slope and rainfall were integrated to demarcate groundwater potential zones in Pravara basin, Maharashtra. All these factors were grouped, and the weighted overlay was performed using influencing factors and frequency ratio techniques. Depending on the results that came out in ArcGIS, the entire study area was divided into five categories of different groundwater potentials: very high, high, moderate, low and very low.

Figure 13 illustrates the groundwater recharge potential map of the Pravara basin through influencing factor technique. By implementing influencing factor, it is observed that about $21 \%, 24 \%, 25 \%, 21 \%$ and $9 \%$ areas are falling under very high, high, moderate, low and very low groundwater potential zones, correspondingly. In case of frequency ratio, the resultant map shows about $32 \%, 24 \%$, $10 \%, 13 \%$ and $21 \%$ areas under very high, high, moderate, low and very low prospect zones, respectively (Fig. 14).

The central and eastern parts of the study area show good-to-moderate groundwater potentiality as this region

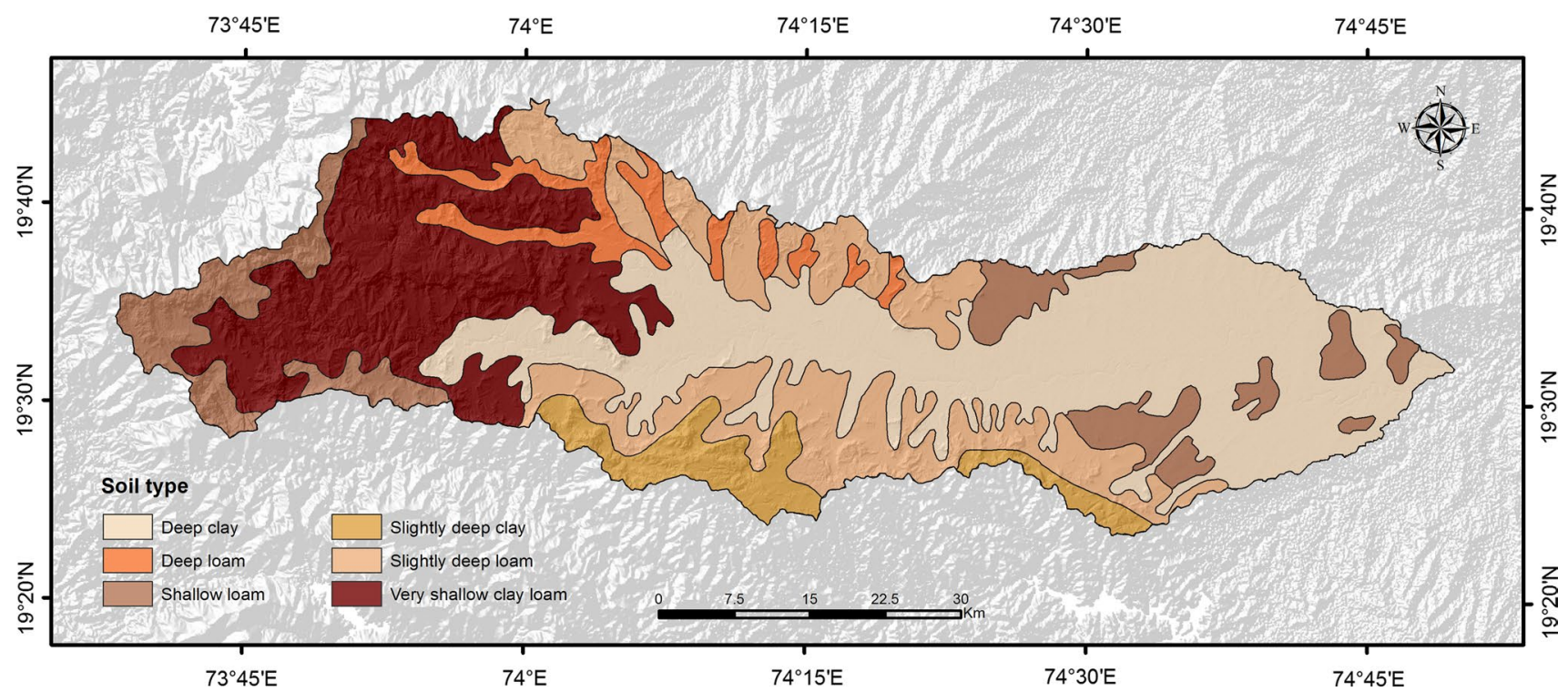

Fig. 12 Distribution of different soil textures in the study area 


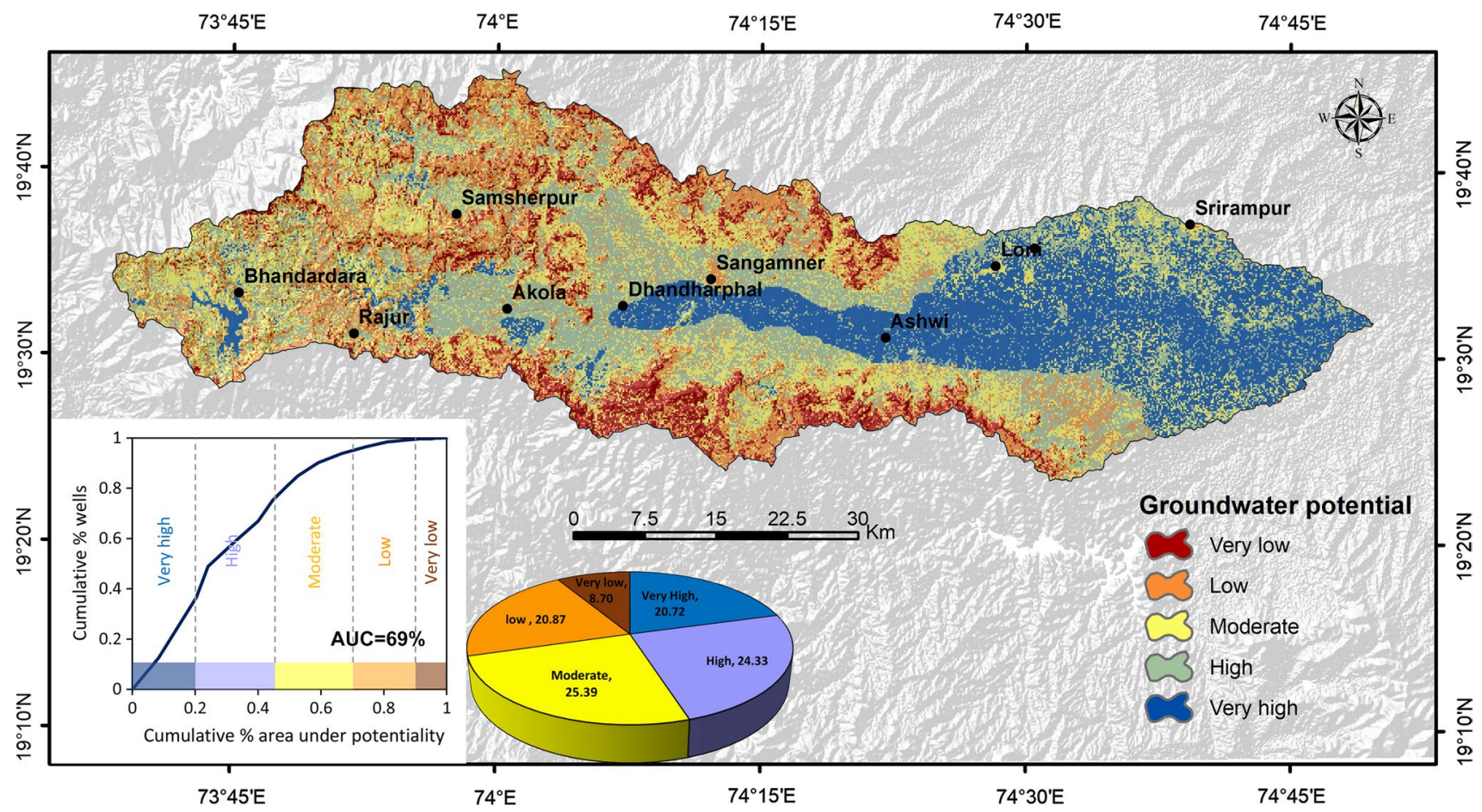

Fig. 13 Groundwater potential map of the study area derived through influencing factors method. Inset dots are showing the major locations in Pravara basin. The relationship between cumulative area

under different potential zones and the cumulative number of wells in the study area is plotted to perform the AUC curve. The pie graph is showing percentage of areas under different potential zones

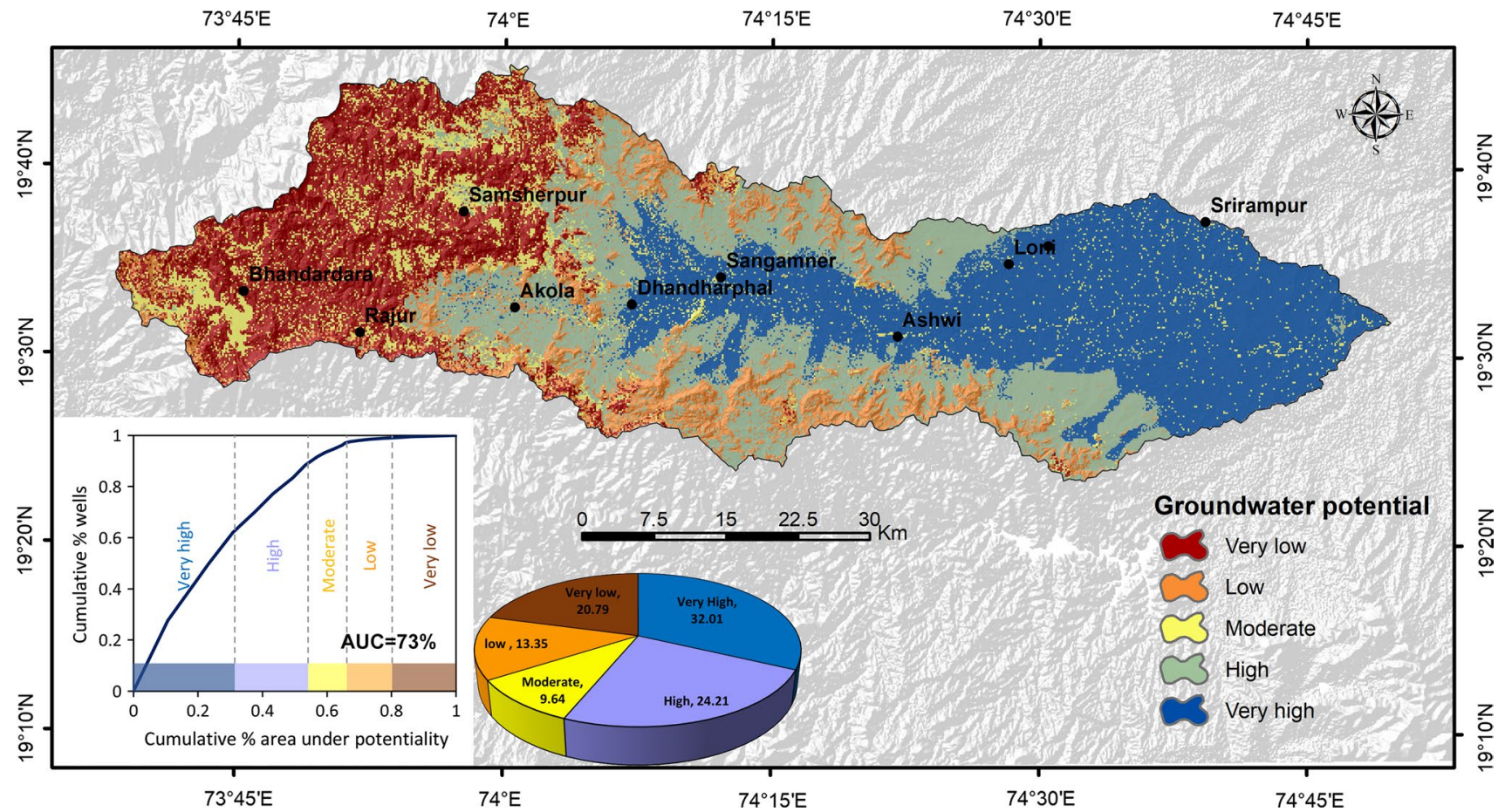

Fig. 14 Groundwater potential map of the study area derived through frequency ratio 
shows very gentle slope, alluvium concentration, agricultural land which influence rapid infiltration process into the sub-surface. Western part of the Pravara basin reflects very poor groundwater potential as the region is having very steep slope, very shallow overlying soil over basaltic lithology. Although the western region shows numerous lineaments, it does not help in this particular region for high groundwater potential due to other factors. The main factors influencing groundwater potential in Pravara basin are slope, lithology and land-use pattern.

\section{Validation of the results}

Validation of the data is one of the most essential works after designing any model in order to check proficiency of the predicted results. To validate the groundwater recharge zones of Pravara basin, at first all the major locations are plotted in the groundwater potential maps. Plotting the major villages and town made it easier to compare the map with existing groundwater reports of CGWB (2014) for Ahmednagar district. It is observed that groundwater potential is higher in the central part of the Pravara basin near Akola, Dhandharphal, Sangamner and Ashwi region. The CGWB (2014) report suggests, the wells located in this region are having a very high yield (Akole-17.92 lps and Sangamner-13.05 lps). Higher yield of an aquifer indicates higher groundwater potential. Hence, these areas identified in this study are extremely suitable for artificial groundwater recharge.

Besides the validation with CGWB report, another attempt has been made to establish a relationship between different groundwater potential zones and the wells available in the study area. Wells are used as a proxy of the groundwater yield as generally a very large number of wells can be found in regions having high groundwater yield. Well inventory is prepared based on the data available in the Survey of India (SOI) topographical map of the study area. Later, the resulting map is classified into twenty equal divisions and number of wells falling in each section is counted to plot the relationship. Area under the curve (AUC) is calculated to verify the accuracy of the model. The AUC shows $73 \%$ accuracy when the model is built using frequency ratio, while $69 \%$ accuracy with influencing factor method (Figs. 13, 14). Although both methods show considerably good accuracy, however, it is recommended to follow the frequency ratio technique as it is based on the statistical ratio between the area under different zones and number of wells. The major drawback of influencing factor technique is that the accuracy of this method depends on the knowledge and the expertise of researchers during ranking the parameters. Additionally, the ranking of influencing factor changes area to area, depending on the available factors.

\section{Conclusion}

Remote sensing and GIS techniques are found to be proficient tools to demarcate groundwater potential zones of Pravara basin, which save money, time and provide quite an accurate result. In the present study, with the help of satellite images and conventional data set, several thematic maps are prepared which affect the groundwater potential of an area. The factors considered in this study to delineate groundwater potential zones are lithology, geomorphology, soil, drainage density, lineament concentration, slope, rainfall and land-use pattern. All these parameters are integrated into GIS software, and the final groundwater potential map is generated. Depending on the groundwater potential map, the study area is categorized into five different zones. The comparison among frequency ratio and influencing factors indicates that the frequency ratio delivers higher accuracy and efficiency (AUC $=73 \%$ ) compared to the influencing factors $(A U C=69 \%)$. The regions having good groundwater potential in the resulting maps may be selected for artificial recharge projects by government or other non-government authorities.

The study is highly valuable towards management and sustainable development of watershed in the Pravara basin. This study provides a simple and systematic method to delineate groundwater recharge potential zones through utilizing modern geospatial techniques. However, this approach can be applied to delineate different groundwater recharge zones in other parts of this world where semi-arid climatic condition and hard-rock lithology are seen.

Acknowledgements The authors wish to thank Enrico Drioli (Editorin-Chief, Applied Water Science), the handling editor for their valuable suggestions in improving the revised manuscript. Critical review and constructive comments from two anonymous reviewers improved the content significantly.

Open Access This article is distributed under the terms of the Creative Commons Attribution 4.0 International License (http://creativeco mmons.org/licenses/by/4.0/), which permits unrestricted use, distribution, and reproduction in any medium, provided you give appropriate credit to the original author(s) and the source, provide a link to the Creative Commons license, and indicate if changes were made.

\section{References}

Anbazhagan S, Balamurugan G, Biswal TK (2011) Remote sensing in delineating deep fracture aquifer zones. Anbazhagan S, Subramanian SK, Yang X (Eds.) Geoinformatics in Applied Geomorphology, CRC Press: Taylor and Francis, pp. 205-229

Alexander PO (1981) Age and duration of Deccan volcanism: K-Ar evidence. In: Subbarao KV, Sukheswala RN (eds) Deccan volcanism and related provinces in other parts of the world, vol 3. Geological Society of India Membership, Bangalore

Arkoprovo B, Adarsa J, Shashi Prakash S (2012) Delineation of groundwater potential zones using satellite remote sensing and

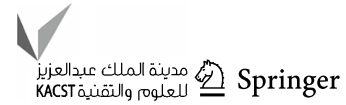


geographic information techniques: a case study from Ganjam district, Orissa, India. Res J Recent Sci 9:59-66

Avtar R, Singh CK, Shashtri S, Singh A, Mukherjee S (2010) Identification and analysis of groundwater potential zones in Ken-Betwa river linking area using remote sensing and geographic information system. Geocarto Int 25(5):379-396

Avtar R, Singh CK, Shashtri S, Mukherjee S (2011a) Identification of erosional and inundation hazard zones in Ken-Betwa river linking area, India, using remote sensing and GIS. Environ Monit Assess 182(1-4):341-360

Avtar R, Singh CK, Singh G, Verma RL, Mukherjee S, Sawada H (2011b) Landslide susceptibility zonation study using remote sensing and GIS technology in the Ken-Betwa River link area, India. Bull Eng Geol Environ 70(4):595-606

Babiker IS, Mohamed AA, Mohamed TH (2007) Assessing groundwater quality using GIS. Water Resour Manag 21:699-715. https ://doi.org/10.1007/s11269-006-9059-6

Bagyaraj M, Ramkumar T, Benkatramanan S, Gurugannam B (2013) Application of remote sensing and GIS analysis for identifying groundwater potential zones in parts of Kodaikanal Taluk, South India. Front Earth Sci 7(1):65-75

Baker ME, Wiley MJ, Carlson ML, Seelbach PW (2003) A GIS model of subsurface water potential for aquatic resource inventory, assessment, and environmental management. Environ Manag 32(6):706-719

Balamurugan G, Karthik S, Somnath B (2017) Frequency ratio model for groundwater potential mapping and its sustainable management in cold desert, India. J King Saud Univ - Sci 29(3):333-347

Bondre NR, Duraiswami RA, Dole G (2004) Morphology and emplacement of flows from the Deccan Volcanic Province. India Bull Volcanol 66:29-45

Bondre NR, Hart WK, Sheth HC (2006) Geology and geochemistry of the Sangamner mafic dike swarm, western Deccan volcanic province, India: implications for regional stratigraphy. J Geol 114:155-170

Brown RJ, Blake S, Bondre NR, Phadnis VM, Self S (2011) 'Áa lava flows in the Deccan Volcanic Province, India, and their significance for the nature of continental flood basalt eruptions. Bull Volcanol 73:737-752

CGWB (2014) Ground water information Ahmednagar district Maharashtra. Ministry of Water Resources, Govt. of India, New Delhi

Cherkauer DS (2004) Quantifying ground water recharge at multiple scales using PRMS and GIS. Ground Water 42(1):97-110

Dar IA, Sankar K, Dar MA (2010) Remote sensing technology and geographic information system modeling: an integrated approach towards the mapping of groundwater potential zones in Hardrock terrain, Mamundiyar basin. J Hydrol 394(3):285-295

Das S (2017) Signatures of morphotectonic activities in western upland Maharashtra and Konkan region. Unpublished M.Sc. thesis, University of Pune

Das S (2018) Geographic information system and AHP-based flood hazard zonation of Vaitarna basin, Maharashtra, India. Arab J Geosci 11(19):576

Das S, Pardeshi SD (2018a) Morphometric analysis of Vaitarna and Ulhas river basins, Maharashtra, India: using geospatial techniques. Appl Water Sci 8(6):158

Das S, Pardeshi SD (2018b) Comparative analysis of lineaments extracted from Cartosat, SRTM and Aster DEM: a study based on four watersheds in Konkan region, India. Spat Inf Res 26(1):4757. https://doi.org/10.1007/s41324-017-0155-x

Das S, Gupta A, Ghosh S (2017) Exploring groundwater potential zones using MIF technique in semi-arid region: a case study of Hingoli district, Maharashtra. Spat Inf Res 25(6):749-756. https ://doi.org/10.1007/s41324-017-0144-0
Das S, Pardeshi SD, Kulkarni PP, Doke A (2018) Extraction of lineaments from different azimuth angles using geospatial techniques: a case study of Pravara basin, Maharashtra, India. Arab J Geosci 11:160. https://doi.org/10.1007/s12517-018-3522-6

Davoodi MD, Rezaei M, Pourghasemi HR, Pourtaghi ZS, Pradhan B (2013) Groundwater spring potential mapping using bivariate statistical model and GIS in the Taleghan watershed Iran. Arab J Geosci 8(2):913-929

Doke A, Pardeshi SD, Pardeshi SS, Das S (2018) Identification of morphogenetic regions and respective geomorphic processes: a GIS approach. Arab J Geosci 11:20. https://doi.org/10.1007/s1251 7-017-3358-5

Elewa HH, Qaddah AA (2011) Groundwater potentiality mapping in the Sinai Peninsula, Egypt, using remote sensing and GIS-watershed-based modeling. Hydrogeol J 19(3):613-628

Ganapuram S, Kumar G, Krishna I, Kahya E, Demirel M (2009) Mapping of groundwater potential zones in the Musi basin using remote sensing and GIS. Adv Eng Softw 40:506-518

Hooper P, Widdowson M, Kelley S (2010) Tectonic setting and timing of the final Deccan flood basalt eruptions. Geol Soc Am 38(9):839-842

Hoque MA, Khan AA, Shamsudduha M, Hossain MS, Islam T, Chowdhury SH (2009) Near surface lithology and spatial variation of arsenic in the shallow groundwater southeastern Bangladesh. Environ Geol 56:1687-1695. https://doi.org/10.1007/s0025 4-008-1267-3

Jenifer MA, Jha MK (2017) Comparison of analytic hierarchy process, catastrophe and entropy techniques for evaluating groundwater prospect of hard-rock aquifer systems. J Hydrol 548:605-624

Jha MK, Peiffer S (2006) Applications of remote sensing and GIS technologies in groundwater hydrology: past, present and future. Bayreuth University Press, Bayreuth

Jha MK, Chowdary VM, Chowdhury A (2010) Groundwater assessment in Salboni Block, West Bengal (India) using remote sensing, geographical information system and multi-criteria decision analysis techniques. Hydrogeol J 18(7):1713-1728

Kellgren N (2002) Applicability of remote sensing techniques to groundwater exploration in semi-arid Hard Rock Terrain-a systematic approach. Publ. no. A 100, PhD Thesis, Chalmers University of Technology, Sweden

Khan MA, Narain P, Moharana PC (2006) Prospecting ground water resources using RS-GIS - a case study from arid western Rajasthan of India. J Indian Soc Remote Sens 34(2):171-179

Kirubakaran M, Johnny JC, Ashokraj C, Arivazagan S (2016) A geostatistical approach for delineating the potential groundwater recharge zones in the hard rock terrain of Tirunelveli taluk, Tamil Nadu, India. Arab J Geosci 9:382

Krishnamurthy J, Kumar NV, Jayraman V, Manivel M (1996) An approach to demarcate groundwater potential zones through remote sensing and GIS. Int J Remote Sens 17(10):1867-1884

Kumanan CJ, Ramasamy SM (2003) Fractures and transmissivity behaviour of the hard rock aquifer system in parts of Western Ghats, Tamil Nadu, India. Water Resour J. pp. 53-59

Kumar T, Gautam AK, Kumar T (2014) Appraising the accuracy of GIS-based multi-criteria decision making technique for delineation of groundwater potential zones. Water Resour Manag 28:4449-4466

Kumari M, Singh CK, Bakimchandra O, Basistha A (2017a) Geographically weighted regression based quantification of rainfalltopography relationship and rainfall gradient in central Himalayas. Int J Climatol 37(3):1299-1309

Kumari M, Singh CK, Bakimchandra O, Basistha A (2017b) DEMbased delineation of improving geostatistical interpolation of rainfall in mountainous region of central Himalayas, India. Theor Appl Climatol 130(1-2):51-58 
Kumari M, Singh CK, Basistha A (2017c) Clustering data and incorporating topographical variables for improving spatial interpolation of rainfall in mountainous region. Water Resour Manag 31(1):425-442

Kumari M, Singh CK, Basistha A, Dorji S, Tamang TB (2017d) Nonstationary modelling framework for rainfall interpolation in complex terrain. Int J Climatol 37(11):4171-4185

Leblanc M, Leduc C, Razack M, Lemoalle J, Dagorne D, Mofor L (2003) Application of remote sensing and GIS for groundwater modeling of large semiarid areas: example of the Lake Chad Basin, Africa. In: Hydrology of mediterranean and semiarid regions conference, Montpellier, France. Red Books Series, 278. IAHS, Wallingford, pp 186-192

Lokesha N, Gopalakrishna GS, Gowdaand H, Gupta AK (2005) Delineation of groundwater potential zones in a hard rock terrain of Mysore district, Karnataka using IRS data and GIS techniques. J Indian Soc Remote Sens 33(3):405-412

Machiwal D, Singh PK (2015) Comparing GIS-based multi-criteria decision-making and Boolean logic modelling approaches for delineating groundwater recharge zones. Arab J Geosci 8(12):10675-10691

Magesh NS, Chandrasekar N, Soundranayagam JP (2012) Delineation of groundwater potential zones in Theni district, Tamil Nadu, using remote sensing, GIS and MIF techniques. Geosci Front 3:189-196

Mallick J, Singh CK, Al-Wadi H, Ahmed M, Rahman A, Shashtri S, Mukherjee S (2015) Geospatial and geostatistical approach for groundwater potential zone delineation. Hydrol Process 29(3):395-418

Manap MA, Sulaiman WNA, Ramli MF, Pradhan B, Surip N (2013) A knowledge-driven GIS modeling technique for groundwater potential mapping at the Upper Langat Basin, Malaysia. Arab J Geosci 6:1621-1637

Manap MA, Nampak H, Pradhan B, Lee S, Sulaiman WNA, Ramli MF (2014) Application of probabilistic-based frequency ratio model in groundwater potential mapping using remote sensing data and GIS. Arab J Geosci 7:711-724

Mehra M, Singh CK (2018) Spatial analysis of soil resources in the Mewat district in the semiarid regions of Haryana, India. Environ Dev Sustain 20(2):661-680

Mehra M, Oinam B, Singh CK (2016) Integrated assessment of groundwater for agricultural use in Mewat district of Haryana, India using geographical information system (GIS). J Indian Soc Remote Sens 44(5):747-758

Mogaji KA, Lim HS, Abdullah K (2015) Regional prediction of groundwater potential mapping in a multifaceted geology terrain using GIS-based Dempster-Shafer model. Arab J Geosci $8: 3225-3258$

Mukherjee S, Shashtri S, Gupta M, Pant MK, Singh C, Singh SK, Srivastava PK, Sharma KK (2007) Integrated water resource management using remote sensing and geophysical techniques: aravali quartzite, Delhi, India. J Environ Hydrol 15(10):1-10

Mukherjee P, Singh CK, Mukherjee S (2012) Delineation of groundwater potential zones in arid region of India- a remote sensing and GIS approach. Water Resour Manag 26(9):2643-2672

Murthy KSR (2000) Ground water potential in a semi-arid region of Andhra Pradesh - a geographical information system approach. Int J Remote Sens 21:1867-1884

Nag SK (2005) Application of lineament density and hydrogeomorphology to delineate groundwater potential zones of Baghmundi block in Purulia district, West Bengal. J Indian Soc Remote Sens 33:521-529

Naghibi SA, Pourghasemi HR, Pourtaghi ZS, Rezaei A (2015) Groundwater qanat potential mapping using frequency ratio and Shannon's entropy models in the Moghan watershed, Iran. Earth Sci Inf 1(8):171-186
Naghibi SA, Pourghasemi HR, Dixon B (2016) Groundwater spring potential using boosted regression tree, classification and regression tree, and random forest machine learning models in Iran. Environ Monit Assess 188:44. https://doi.org/10.1007/s1066 $1-015-5049-6$

Ozdemir A (2011) GIS-based groundwater spring potential mapping in the Sultan Mountains (Konya, Turkey) using frequency ratio, weights of evidence and logistic regression methods and their comparison. J Hydrol 411(3-4):290-308

Pande CB, Khadri SFR, Moharir KN, Patode RS (2017) Assessment of groundwater potential zonation of Mahesh river basin Akola and Buldhana district, Maharashtra, India using remote sensing and GIS techniques. Sustain Water Resour Manag. https://doi. org/10.1007/s40899-017-0193-5

Pourtaghi ZS, Pourghasemi HR (2014) GIS-based groundwater spring potential assessment and mapping in the Birjand Township, southern Khorasan Province Iran. Hydrogeol J. https://doi.org/10.1007/ s10040-013-1089-6

Pradhan B (2009) Groundwater potential zonation for basaltic watersheds using satellite remote sensing data and GIS techniques. Cent Eur J Geosci 1(1):120-129

Prasad RK, Mondal NC, Banerjee P, Nandakumar MV, Singh VS (2008) Deciphering potential groundwater zone in hard rock through the application of GIS. Environ Geol 55(3):467-475

Rahmati O, Samani AN, Mahdavi M, Pourghasemi HR, Zeinivand H (2015) Groundwater potential mapping at Kurdistan region of Iran using analytic hierarchy process and GIS. Arab J Geosci 8(9):7059-7071

Rao YS, Jugran DK (2003) Delineation of groundwater potential zones and zones of groundwater quality suitable for domestic purposes using remote sensing and GIS. Hydrol Sci J 48(5):821-833

Roy S, Sahu AS (2016) Effectiveness of basin morphometry, remote sensing, and applied geosciences on groundwater recharge potential mapping: a comparative study within a small watershed. Front Earth Sci 10(2):274-291

Sander P, Chesley M, Minor T (1996) Groundwater assessment using remote sensing and GIS in a rural groundwater project in Ghana: lessons learned. Hydrogeol J 4:78-93

Satpathy BN, Kanungo BN (1976) Groundwater exploration in Hard rock terrain - a case study. Geophys Prospect 24(4):725-763

Sener E, Davraz A, Ozcelik M (2005) An integration of GIS and remote sensing in groundwater investigations: a case study in Burdur, Turkey. Hydrogeol J 13:826-834

Singh S, Singh C, Mukherjee S (2010) Impact of land-use and landcover change on groundwater quality in the Lower Shiwalik hills: a remote sensing and GIS based approach. Open Geosci 2(2):124-131

Singh CK, Shashtri S, Mukherjee S, Kumari R, Avatar R, Singh A, Singh RP (2011a) Application of GWQI to assess effect of land use change on groundwater quality in lower Shiwaliks of Punjab: remote sensing and GIS based approach. Water Resour Manag 25(7):1881-1898

Singh CK, Shashtri S, Singh A, Mukherjee S (2011b) Quantitative modelling of groundwater in Satluj river basin of Rupnagar district of Punjab using remote sensing and geographic information system. Environ Earth Sci 62(4):871-881

Solomon S, Quiel F (2006) Groundwater study using remote sensing and geographic information system (GIS) in the central highlands of Eritrea. Hydrogeol J 14(5):729-741

Tahmassebipoor N, Rahmati O, Noormohamadi F, Lee S (2016) Spatial analysis of groundwater potential using weights-of-evidence and evidential belief function models and remote sensing. Arab J Geosci 9:79

Thomas R, Duraisamy V (2017) Hydrological delineation of groundwater vulnerability of droughts in semi-arid areas of western

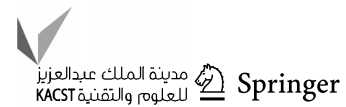


Ahmednagar district. Egypt J Remote Sens Space Sci. https:// doi.org/10.1016/j.ejrs.2016.11.008

Todd DK, Mays LW (2005) Groundwater hydrology, 3rd edn. Wiley, Hoboken

Wellman P, McElhinny MW (1970) K-Ar age of the Deccan Trap, India. Nature 227:595-596

Widdowson M, Mitchel C (1999) Large scale stratigraphical, structural and geomorphological constraints for earthquakes in the southern Deccan Traps, India: the case for denudationally-driven seismicity. Geol Soc India Mem 43:425-452

World Water Assessment Programme (WWAP) (2009) Water in a changing world. World Water Development Report 3. UNESCO, Paris
Yeh H-F, Lee C-H, Hsu K-C, Chang P-H (2009) GIS for the assessment of the groundwater recharge potential zone. Environ Geol 58(1):185-195

Publisher's Note Springer Nature remains neutral with regard to jurisdictional claims in published maps and institutional affiliations. 